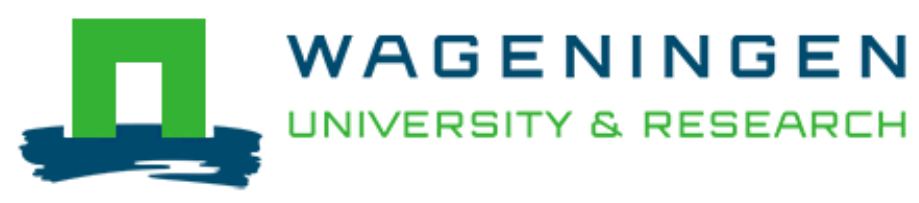

Consumer entrepreneurship: What is it? When, how, and why does it emerge?

Dentoni, D., Poldner, K., Pascucci, S., \& Gartner, W. B.

This is a "Post-Print" accepted manuscript, which has been published in "None"

This version is distributed under a non-commercial no derivatives Creative Commons (c) $(1) \Theta(9$ user license, which permits use, distribution, and reproduction in any medium, provided the original work is properly cited and not used for commercial purposes. Further, the restriction applies that if you remix, transform, or build upon the material, you may not distribute the modified material.

Please cite this publication as follows:

Dentoni, D., Poldner, K., Pascucci, S., \& Gartner, W. B. (2017). Consumer entrepreneurship: What is it? When, how, and why does it emerge? In Advances in Entrepreneurship, Firm Emergence and Growth (Vol. 19, pp. 187-218). (Advances in Entrepreneurship, Firm Emergence and Growth; Vol. 19). Emerald. DOI:

10.1108/S1074-754020170000019006

You can download the published version at:

https://doi.org/10.1108/S1074-754020170000019006 
Book chapter published on:

Corbett, A. C., \& Katz, J. A. (Eds.). (2017). Hybrid Ventures. Emerald Publishing Limited.

Title:

Consumer entrepreneurship: What is it? When, how and why does it emerge?

Authors:

Dr. Domenico Dentoni, Management Studies Group, Wageningen University \& Research, Wageningen (The Netherlands)

Prof. William Gartner, Department of Management, Politics and Philosophy, Copenhagen Business School, Copenhagen (Denmark)

Prof. Stefano Pascucci, Exeter Business School, Penryn (United Kingdom)

Dr. Kim Poldner, Management Studies Group, Wageningen University \& Research, Wageningen (The Netherlands)

Please cite as:

Dentoni, D., Poldner, K., Pascucci, S., \& Gartner, W. B. (2017). Consumer

Entrepreneurship: What Is It? When, How, and Why Does It Emerge? In Corbett, A. C., \& Katz, J. A. (Eds.), Hybrid Ventures (pp. 187-218). Emerald Publishing Limited. 


\title{
Consumer entrepreneurship: What is it? When, how and why does it emerge?
}

\section{Domenico Dentoni, Kim Poldner, Stefano Pascucci, William Gartner}

\begin{abstract}
The objective of this chapter is to understand innovative processes of resource redeployment taking place during consumption. We label this: consumer entrepreneurship. We define consumer entrepreneurship as the process of sharing and recombining resources innovatively to seek opportunities for self-creating user value. Through the illustration of heterogeneous forms of consumer peer-to-peer sharing, we argue that consumer entrepreneurship: 1) differs ontologically from a view of entrepreneurship as creation of exchange value; 2) bridges the notion, established in marketing studies, of consumers as value creators with the field of entrepreneurship; 3) develops mostly when the process of sharing is regulated informally, based on trust relationships; and 4) thrives as groups of sharing consumers discover and enact their values through the experimentation of multiple forms of product and service procurement. On the basis of these points, consumer entrepreneurship contributes to provide a novel perspective on hybrid organizations, that is, a view of hybrid organizations as everyday spaces where consumers create heterogeneous forms of (utilitarian, social or environmental) value that they personally use as opposed to reward exchanges. Relative to the current definition of hybrid organizations (Pache and Santos 2013) and organizing (Battilana and Lee 2014), we argue that consumer entrepreneurship helps better explain "why, when and how" consumers increasingly engage in peer-to-peer sharing organizationsa fledging and still underexplored way of organizing consumption worldwide.
\end{abstract}

\section{Introduction}

This chapter seeks to understand and explain the activities consumers actually engage in during peer-to-peer sharing. We will argue, in this chapter, that peer-to-peer sharing is a form of hybrid organizing (Battilana and Lee 2014) that relies on the self-creation of user value. In peer-to-peer sharing, consumers pool and co-access resources with other consuming peers beyond the traditional boundaries of their household, family and friends - in multiple facets of their life (e.g. cars, bikes, pictures, houses, clothes, energy, agricultural land and food among the others). Accordingly, while the literature has numerous examples what sharing entails regarding which resources are shared and why consumers share (Belk 2010; 2014), we still know relatively little on what consumers actually do when they engage in peer-to-peer 
sharing. Do their practices differ from consumers that do not share the same resources? Why so? Do their practices vary when consumers engage in different forms of emerging peer-topeer sharing organizations? And how do these practices evolve over time in the sharing process? These questions have wide societal relevance. As an everyday life activity, what consumers do when engaging in peer-to-peer sharing influences their self-confidence, empowerment, lifestyle and their overall well-being. While consumer scholars have recently studied processes of self-organized consumption (e.g. Scaraboto 2015), an entrepreneurial view on these peer-to-peer sharing groups has still not been elaborated. This is a notable gap, as understanding the entrepreneurial nature of consumers in peer-to-peer sharing may provide novel theoretical insights on processes of hybrid organizing in everyday life (Steyaert and Katz 2004).

Perhaps not surprisingly, the starting point of our argument is that - in some forms and circumstances of peer-to-peer sharing - consumers engage in entrepreneurial practices. More specifically, consumers engage in a collective process of innovatively recombining resources to seek opportunities for self-creating user value during their own consumption or, as we suggest defining it, consumer entrepreneurship. In the next section of this chapter, we argue that consumer entrepreneurship differs ontologically from the established concepts of user entrepreneurship and of consumers as value creators - while it resonates with the idea of entrepreneurship as a social practice taking place in everyday life (Johannisson, 2011; Nicolini, 2012; Schatzki, 1996; Steyaert and Katz 2004; Turner, 2001). In the third section, we zoom in on the boundaries of consumer entrepreneurship: what is it and what is it not? We argue that consumer entrepreneurship is inherently related to peer-to-peer sharing since the locus of consumer value creation expands relative to more traditional forms of sharing (e.g. within a household or circles of family and friends). More specifically, we suggest that different consumers' entrepreneurial practices develop depending on the organization of the sharing process. In other words, the form of peer-to-peer sharing organization influences - or perhaps co-evolves with - the entrepreneurial practices of their members (section 4). In the fifth section, we dig into the dynamics linking consumer practices and the form of their peerto-peer sharing organizations to their underlying logics. Finally, on the basis of these arguments, we discuss how consumer entrepreneurship in peer-to-peer sharing groups contributes to shed light on how hybrid organizing evolves in everyday life (section 6).

Differently from the contexts of existing organizations (family, informal networks, public institutions) where everyday entrepreneurship has been studied so far (Steyaert and Katz 2004), the locus of consumer entrepreneurship involves a novel space - a peer-to-peer 
sharing organizations - where consumers create heterogeneous forms of value (utilitarian, social or environmental) that they personally use as opposed to exchange for a reward. Relative to the established definitions of hybrid organizations (Pache and Santos 2013) and organizing (Battilana and Lee 2014), we argue that consumer entrepreneurship helps better explain why, when and how consumers increasingly engage in self-organized forms that discover, develop and integrate multiple logics. From a perspective of today’s social, economic and environmental challenges, these forms of hybrid organizing in everyday life seem to reflect individual and community responses to engage in meaningful practices to address the complexity of problems that they seek to address (Lichtenstein et al. 2007; Ferraro et al. 2015).

To illustrate what consumers do in peer-to-peer sharing organizations - as well as when, how and why their practices emerge - we develop a set of conceptual arguments based on empirical illustrations and we use entrepreneurship theory as an interpretative lens. We provide illustrative examples of peer-to-peer sharing organizations in food, agriculture and energy sectors that we have studied in the Netherlands, Germany, Spain and Italy since 2011 (Pascucci et al. 2011; Dentoni et al. 2015). In the Netherlands and Spain, similar to many other Western countries, community-supported agriculture and community gardens involve consumers and farmers (up to 60 or even 100 members) sharing land and its products (fruit, vegetables, legumes and dairy among the others) for self-consumption since 1990s. In the same timeframe and similar participant numbers, solidarity purchasing groups in Italy and consumer groups in Spain self-organize the procurement, transport and distribution of food from farm to members' house doors. In Germany and the Netherlands, neighbor communities have emerged since the early 2000s to co-access wind turbines and solar panels, thus sharing alternative energy forms. Despite the policy changes and institutional uncertainty regulating these organizations, these forms of peer-to-peer sharing have continued to grow larger than ever. While these sharing groups, in the context of food, agriculture and energy sectors have been widely studied (e.g. Sage 2003), as types of organizational forms (Pascucci et al. 2013; Miralles et al. 2017) and while these sharing groups resemble examples of collective organizations, [such as early examples of kibbutzim in Israel (Simons and Ingram 1997) or barter networks in transition economies (Seabright 2000)] in the nature of their resource base, and in exchanges among members and intentionality, these previous efforts have not taken an entrepreneurship theory lens to these phenomena.

\section{Entrepreneurship and the self-creation of user value}


To explain the nature of consumer practices in peer-to-peer sharing as entrepreneurial, we shortly summarize some key points regarding the nature of entrepreneurship. Since the 1980s, scholars established a largely agreed view of entrepreneurship as inherently related to the emergence of new organizations (Katz and Gartner 1988). Entrepreneurship entails many facets around the creation of a new venture including the individual, the new venture, the external environment and the processes linking them (Gartner 1985). During the 1990s, one of the questions that emerged in the debate was: does entrepreneurship take place only around the creation of new ventures or does it extend also to processes within existing ventures or connecting multiple actors in society? Over time, scholars have been increasingly supporting of the latter perspective, which was conveyed as a process of recombining resources innovatively to seize or create opportunities for value creation (Shane and Venkataraman 2000). A much broader range of phenomena were then studied under the lens of entrepreneurship. Among others, these included the study of business practices in existing ventures (e.g. intrapreneurship), practices seeking opportunities to the creation of social value along with business value (e.g. social entrepreneurship) and the value creation processes in indigenous communities (e.g., community-based entrepreneurship). Within this debate, the concept of consumer entrepreneurship resonates with the broader perspective of entrepreneurship beyond new venture creation conveyed by Shane and Venkataraman (2000) in the early 2000s.

Table 1: Positioning the concept of consumer entrepreneurship in the existing literature on entrepreneurship and consumer studies.

\begin{tabular}{|l|l|l|l|}
\hline \multirow{2}{*}{$\begin{array}{l}\text { Consumer } \\
\text { entrepreneurship }\end{array}$} & \multicolumn{2}{|l|}{$\begin{array}{l}\text { Proposed definition } \\
\text { The process of recombining resources innovatively to seek opportunities for self- } \\
\text { creating user value during consumption. }\end{array}$} \\
\cline { 2 - 4 } $\begin{array}{l}\text { Similar yet } \\
\text { different concepts } \\
\text { from consumer } \\
\text { entrepreneurship: }\end{array}$ & $\begin{array}{l}\text { Papers providing key } \\
\text { definitions }\end{array}$ & $\begin{array}{l}\text { Key difference from } \\
\text { consumer } \\
\text { entrepreneurship }\end{array}$ & $\begin{array}{l}\text { Key similarity with } \\
\text { consumer entrepreneurship }\end{array}$ \\
\hline $\begin{array}{l}\text { Social } \\
\text { entrepreneurship }\end{array}$ & $\begin{array}{l}\text { Seelos and Mair } \\
\text { (2005); Mair and Marti } \\
\text { (2006), Austin and } \\
\text { Stevenson (2006); } \\
\text { Peredo and McLean } \\
\text { (2006); Di Domenico }\end{array}$ & $\begin{array}{l}\text { Does not involve the self- } \\
\text { creation of user value: the } \\
\text { social entrepreneur creates } \\
\text { value to customers or } \\
\text { beneficiaries in exchange of } \\
\text { returns from customers and }\end{array}$ & $\begin{array}{l}\text { Involves processes of } \\
\text { innovative resource } \\
\text { recombination to create value } \\
\text { (e.g. voluntary organizations } \\
\text { recombine their volunteers' } \\
\text { time, spaces and networks to }\end{array}$ \\
\hline
\end{tabular}




\begin{tabular}{|c|c|c|c|}
\hline & et al. (2010). & $\begin{array}{l}\text { other stakeholders } \\
\text { (government, civil society, } \\
\text { foundations). }\end{array}$ & $\begin{array}{l}\text { provide assistance to } \\
\text { marginalized actors in } \\
\text { society). }\end{array}$ \\
\hline $\begin{array}{l}\text { User } \\
\text { entrepreneurship }\end{array}$ & $\begin{array}{l}\text { Shah and Tripsas } \\
\text { (2007); Chandra and } \\
\text { Coviello (2010); } \\
\text { Chandra and Leenders } \\
\text { (2012). }\end{array}$ & $\begin{array}{l}\text { Does not involve the self- } \\
\text { creation of user value: the } \\
\text { user entrepreneur creates } \\
\text { value to (formerly peer) } \\
\text { customers in exchange of } \\
\text { returns from them. }\end{array}$ & $\begin{array}{l}\text { Involves processes of } \\
\text { innovative resource } \\
\text { recombination to create value } \\
\text { (e.g. former juvenile product } \\
\text { users recombine their user } \\
\text { experience, networks and } \\
\text { capital to develop more user- } \\
\text { friendly products). }\end{array}$ \\
\hline $\begin{array}{l}\text { Community- } \\
\text { based } \\
\text { entrepreneurship }\end{array}$ & $\begin{array}{l}\text { Peredo and Chrisman } \\
\text { (2006); Marti et al. } \\
\text { (2013); Webb et al. } \\
\text { (2013). }\end{array}$ & $\begin{array}{l}\text { As described so far in the } \\
\text { cited literature, it only } \\
\text { partially involves the self- } \\
\text { creation of user value: } \\
\text { community members } \\
\text { exchange resources } \\
\text { internally (i.e., self-creation } \\
\text { of value) to create value to } \\
\text { stakeholders outside the } \\
\text { community boundaries in } \\
\text { exchange of returns from } \\
\text { them (i.e. exchange value as } \\
\text { opposed to user value). }\end{array}$ & $\begin{array}{l}\text { Involves processes of } \\
\text { innovative resource } \\
\text { recombination to create value } \\
\text { (e.g. indigenous community } \\
\text { members recombine spaces, } \\
\text { artefacts and capital to enter } \\
\text { new markets while reducing } \\
\text { risks). }\end{array}$ \\
\hline $\begin{array}{l}\text { Consumer as } \\
\text { value creator }\end{array}$ & $\begin{array}{l}\text { Grönroos (2011); } \\
\text { Grönroos and Ravald } \\
\text { (2011); Heinonen et al. } \\
\text { (2010); Helkkula et al. } \\
\text { (2012). }\end{array}$ & $\begin{array}{l}\text { Does not involve a process } \\
\text { of recombining resources } \\
\text { innovatively: the consumers } \\
\text { self-create user value } \\
\text { according to the rules set by } \\
\text { the firm selling them the } \\
\text { product or service. In other } \\
\text { words, the resource } \\
\text { recombination process is not } \\
\text { entrepreneurial. }\end{array}$ & $\begin{array}{l}\text { Involves the consumer self- } \\
\text { creation of user value: } \\
\text { consumers give meanings to } \\
\text { their use of products; add } \\
\text { their own resources to } \\
\text { products; and expand their } \\
\text { locus of value creation } \\
\text { through interactions (e.g. } \\
\text { with suppliers or with other } \\
\text { buyers). }\end{array}$ \\
\hline
\end{tabular}

Relative to these phenomena interpreted according to a more inclusive view of entrepreneurship (Shane and Venkataraman 2000), the difference of consumer entrepreneurship lies in the nature of the value created in entrepreneurial processes (Table 1). Most entrepreneurship theories developed in recent years - such as social entrepreneurship, intrapreneurship and community-based entrepreneurship - see the creation of exchange value as the core of entrepreneurial processes. This involves recombining resources innovatively to create value for others that, in exchange, provide the value-creator with monetary or other types of rewards (Bowman and Ambrosini 2000; Priem 2007), for example legitimacy, reputation, access of networks or knowledge. For example, social entrepreneurship involves the creation of value for others outside the value-creating individual or organization, seeking returns (either monetary or non-monetary, and either direct or indirect) as an exchange 
(Austin et al. 2006; Mair and Marti 2006). A healthcare organization, may engage in recombining volunteers, staff, equipment and partners innovatively to provide assistance to needy patients and - indirectly through the reputation and legitimacy that they gain - receive (in exchange) financial support from public (e.g., government) or private actors (e.g. NGOs). Intrapreneurship entails reconfiguring resources within an existing organization to create, for example, more appealing products, more efficient processes or more effective knowledge sharing practices among employees (Antoncic and Hisrich 2001). In this case, intrapreneurship is driven and motivated by exchanging value that brings returns to the intrapreneurs in terms of better deals with customers or suppliers, better contracts or other forms of recognition from others within the company. Finally, community-based entrepreneurship has so far been explained around the notion of exchange value (Peredo and Chrisman 2006). For example, members of indigenous communities engage in a multitude of informal exchanges facilitated by trust relationships and a common identity. The trust among members allows them to recombine resources that create value for the community (Peredo and Chrisman 2006). While the communities may have the goal of self-creating value for their members, the development of entrepreneurship in communities has so far mostly focused on the creation of value with actors outside their boundaries, therefore focusing on the exchange value as opposed to the user value created by the communities (Peredo and Chrisman 2006; Marti et al. 2013).

As opposed to the creation of exchange value, what we call consumer entrepreneurship involves the self-creation of user value (Proposition 1). We provide this as proposition 1.

\section{Proposition 1:}

\section{Consumer entrepreneurship involves the self-creation of user value.}

Consumers share and recombine resources with each other to seek opportunities to create value for themselves and for the other sharing peers. Three solidarity purchasing groups in Sicily (Southern Italy) were the first example where we stumbled across this phenomenon (Pascucci et al. 2013; Cembalo et al. 2013, 2015). Similarly, other illustrations in the past literature that may resemble the peer-to-peer sharing organizations that we observed may be traced back to early examples of kibbutzim in Israel (Simons and Ingram 1997) or barter networks in transition economies (Seabright 2000). From an entrepreneurial lens, in these peer-to-peer sharing groups, members develop and share food inventories with one or more 
farmers to obtain a balanced amount of fruit, vegetables, eggs and legumes to compose weekly meals among sharing peers. Others organize events to share knowledge on their jointly purchased food, strengthen their networks with farmers, and gain more awareness on the process that they are engaged in. We realized that, first of all, members' actions entail recombination of a range of resources that were shared in the group - cars, storage space, funds, networks, a wide range of knowledge and information. Moreover, their actions are often innovative, that is, not prescribed by other members nor following the example of others, but rooted in their own ideas and interest in experimenting in new ways of doing things. Finally, instead of seeking value-creating opportunities for an exchange, they sought opportunities for self-creating their own user value - in other words, they act as consumers of their own value creation process. Of course, these consumer groups may also involve informal mechanisms of exchange among members. For example, as some peers develop new ways of procuring food from farmers, these other members may feel compelled or expected to seek other forms of value creation. In other words, reciprocity may become a routine to exchange value among peers. Yet, what we ultimately found is that: consumer entrepreneurship inherently comes down to the self-creation of user value during consumption rather than creating value and exchanging it with others for a reward. For example, the consumer entrepreneur may engage with farmers to learn about the source of food, or to enjoy the experience of visiting farmers and consuming food in a social setting. Given their self-creating nature of user value, then, the example of Italian solidarity purchasing groups, similar consumer peer-to-peer sharing in the Netherlands, Germany and Spain, resonate with the notion of entrepreneurship as a practice taking place in everyday life (Steyaert and Katz 2004; Staeyert 2007).

This distinction between the creation of exchange value and the self-creation of user value provides a boundary between consumer entrepreneurship and the established notion of user entrepreneurship (Shah and Tripsas 2007). The idea of user entrepreneurship implies that frequent users of products and services may develop the resources (e.g. expertise, networks, trust relationships) and recombine them to create value. In other words, users may have an advantage in discovering and pursuing opportunities for value creation (Shah and Tripsas 2007; Chandra and Coviello 2010; Priem et al. 2012). For example, parents adapting and customizing children's products are considered to be in the best market position to create value for other parents with similar needs, because they learned consumer needs from their own consumption experience (Shah and Tripsas 2007). As a second example, eBay or SecondLife users may be best positioned in the marketplace to serve peer users because they 
may become more knowledgeable of eBay and SecondLife consumer needs (Chandra and Coviello 2010; Chandra and Leenders 2012). This view of user entrepreneurship assumes that consumers are entrepreneurs only in their act of creating exchange value (Priem 2007), that is, when they sell their products to other consumers or peers. Even when the described entrepreneurial process is "accidental” rather than planned (Shah and Tripsas 2007), consumers are considered as entrepreneurs only at the point when they create a new venture that creates and exchanges value with customers. Therefore, despite the similarity in the term “user”, the ontological difference (Sánchez-Fernández, Iniesta-Bonillo, 2007; Sheth \& Uslay, 2007; Stark, 2011). - grounded in different interpretations of what value creation and value itself is, i.e. user value versus exchange value - with what entrepreneurship entails in consumer peer-to-peer sharing groups is profound. This insight will be elaborated on in the next section.

\section{Marketing and consumer studies: The role of consumer as value creator}

To fully embed and understand the concept of consumer entrepreneurship in the existing literature, we need to position it also in relation to the recent developments in the field of marketing and consumer studies. A recent strand of the service marketing literature established the notion that customers participate to the creation of value during consumption (Grönroos 2011; Grönroos and Ravald 2011; Heinonen et al. 2010; Helkkula et al. 2012). This concept is particularly relevant to understand what takes place in consumer peer-to-peer sharing examples that give ground to consumer entrepreneurship. In particular, building upon the framework developed by Grönroos and Voima (2013), three elements are central to provide theoretical ground on what consumer entrepreneurship is, as well as when and why it takes place: the nature of consumer value; the role of consumers as value creators; and the locus of value creation. These elements are essential to shed light on why consumers engage with products in interaction with each other, such as in sharing consumer groups.

The first theoretical advance where the field of marketing and consumer studies helps us to understand consumer entrepreneurship involves the nature of consumer value. Looking from a constructivist perspective, consumers may give different value to a product or service depending on their interaction with it and on the context of consumption (Sánchez and Iniesta 2007). For example, value may vary in comparison with other products and services. Consumers’ preferences, perceptions, and rational or affective processes come to play in assessing value (Sánchez and Iniesta 2007). When giving value to products and services, consumers may assess beyond their functional dimension (e.g. flavor, calories, nutrients of 
food). Instead, they may give them social, emotional and even epistemic meanings (Sheth et al. 1991). For example, people may have fun, expand their knowledge or even have epiphanies when procuring, preparing and enjoying food, energy or clothes, with positive and even transformational effects on their life. Value may reflect the entertainment of consuming, thus having also experiential, affective, visual and interactive dimensions (Babin et al. 1994; Lee and Overby 2004). As a synthesis of these various dimensions of perceived value, Holbrook $(1994,1999)$ provides typologies of perceived value along three dichotomies: "extrinsic or intrinsic (a product viewed instrumentally as a means to some end versus a consumption experience prized for its own sake as an end in itself); self-oriented or otheroriented (something valued by virtue of the effect it has on oneself or for one's own sake versus an aspect of consumption positively evaluated because of how others respond or for the sake of someone else); and active or reactive (involving the manipulation of some product by its user versus the appreciation of some consumption experience wherein an object affects oneself rather than vice versa)” (Sánchez and Iniesta 2007, p. 439). These dichotomies describe the variety of user values that may move consumers in self-creating processes to engage with sharing peers. The idea that entrepreneurs may give different value to the same resources is not new in entrepreneurship (e.g., as in entrepreneurial bricolage, Baker and Nelson 2005). Instead, the notion that consumers may give different values to their use, depending on their own preferences, is critical to understand why some consumers may engage in entrepreneurial practice during consumption (as in consumer peer-to-peer sharing groups) and others do not.

The second critical element that consumer entrepreneurship borrows from the field of marketing and consumer studies is the role of consumer as value creator. This refers to customers' creation of value-in-use, that is, during the consumption of the product or service (Grönroos and Voima 2013). "Consumers do not buy goods or services: they buy offerings, which render services, which create value” (Gummesson 1995, pp. 250-51). During consumption itself, the consumer is always involved in the production of value. Even when engaging with a product for its functional use, production does not end with the manufacturing process. Instead, production is an intermediary process. For example, in using a drill, the customer adapts its use to the features of the wall, the drill tip and the fit between the pictures to hang and the room where the drill is used. Furthermore, after use the customer preserves it and seeks to maximize its use, for example make it available to other members of her family or neighbors. In doing so, the customer continues a value-creating adaptation, marketing, and delivery process after purchase (Vargo and Lusch 2004). Most of these 
consumer value-creating practices are every-day, mundane, spontaneous and sometimes even unconscious (Schatzki 1996; Thompson et al. 1989). As such, along with value creation, these practices have been also referred to as value emergence or formation (e.g., Echeverri and Skålen 2011; Grönroos 2011). In the field of marketing and consumer studies, understanding consumer value-creation practices has critical implications for firms selling products and services to consumers. For our purposes, we expand this notion to discuss how consumers may engage in spontaneous forms of recombining resources - as opposed to guided forms of resource recombination that are pre-established by the firms selling to consumers. The term “value emergence” (Echeverri and Skålen 2011; Grönroos 2011) describes particularly well the nature of consumer entrepreneurial practices that we empirically observed in peer-to-peer sharing groups, since consumers seem to make sense on what they really value during their entrepreneurial process, itself: we will discuss this point further in section 5 .

The third essential element that consumer entrepreneurship borrows from the field of marketing and consumer studies is the locus of value creation. This is "the customer's physical, mental, or possessive activities, practices, and experiences in multiple individual and social contexts” (Grönroos and Voima 2013, p. 138). Therefore, the forms of interaction among producers and consumers influence the value creation process and, as such, this is also referred to as co-creation (Grönroos and Voima 2013). More broadly, the network context in which value creation often takes place is critical to explain consumers' participation to value co-creation (Gummesson 2006). When observing consumer peer-to-peer sharing groups, the locus of consumer value creation expands relative to the co-creation undertaken by a producer and a consumer (Grönroos and Voima 2013). Given the wider locus of value creation, for example, consumers in Italian solidarity purchasing groups share final goods with each other and/or reach out to interact with the primary resources necessary to generate those final goods (land, agricultural inputs, turbines to create energy). As such, consumers expand the locus of value creation through sharing practices (Bardhi and Eckhardt 2012; Lamberton and Rose 2012). When elaborating on the notion of value co-creation between producer and consumer (Grönroos and Voima 2013), the context of sharing illustrates that interaction among consumers can co-create value as well. To describe processes of value cocreation among consumers with an expanded locus, recent consumer studies introduced the concept of “prosumption” (Ritzer and Jurgenson 2010). For example, consumers of social media (e.g. Instagram, Facebook or Wikipedia) are, at the same time, producers for their sharing peers in a locus of value co-creation vastly augmented in digital environments. While 
the concept of prosumption and consumer entrepreneurship are both ground in examples of an increased locus for value co-creation among consumers, they differ in their focus on the process of the recombination of resources. While, for example, consumers in Italian solidarity purchasing groups recombine resources innovatively to create value - or, in other words, have control of their "space to play" (Hjorth 2004) in recombining resources - consumers creating value in the digital space operate under a set of processes preconfigured by the firms providing the space (e.g. Instagram, Facebook or Wikipedia; with the exception of open software programming such as Linux, allowing its users to operate in a self-regulated space for resource recombination).

These three elements borrowed from marketing and consumer studies - marshalled with a broader view of entrepreneurship as a process of recombining resources innovatively to create opportunities for value creation (Section 2) - set the boundaries for us to define what consumer entrepreneurship appears to be - and position it relative to recent studies in entrepreneurship and consumer studies. We define consumer entrepreneurship as the process of sharing and recombining resources innovatively to seek opportunities for self-creating user value. Does this definition of consumer entrepreneurship imply that every consumer for example when learning how to cook a new recipe, walking the dog with friends or finding creative ways to let their baby fall asleep - may be considered as an entrepreneur? Potentially, these everyday actions could indeed be entrepreneurial, yet, because of the limited locus of value creation, it is hard for consumers as individuals, or atomized in small households or small networks of family and friends, to engage in innovative resource recombination processes. In other words, the process of sharing resources in an organization or group larger than a household or a circle of family and friends increases the opportunities that consumers are more likely to innovatively recombine resources - as our first illustrations from the solidarity purchasing groups in Sicily demonstrate. Reiterating a point made earlier, a very different situation, user entrepreneurship, occurs when a consumer uses value as a conscious effort to prelude to new organization creation. A typical example of user entrepreneurship (Shah and Tripsas 2007; Chandra and Leenders 2012), is where the process of value use and value creation are subsequent rather than simultaneous, as discussed in section 2 . The critical role of an extended locus of value creation (i.e., peer-to-peer sharing group beyond household or family and friends) in consumer entrepreneurship makes it necessary to analyze the organizational factors when consumers mostly engage in entrepreneurial practices. This will be the focus on section 4 . 


\section{When and how does consumer entrepreneurship emerge?}

Realizing that consumers were engaging in an innovative recombination of resources for their own user value creation in Italian solidarity purchasing groups - what we called consumer entrepreneurship - we went began to explore whether other peer-to-peer consumer groups across Europe were undertaking similar entrepreneurial practices or not. We purposively looked for consumer groups that organized themselves differently from each other - to explore if and how their organization form may relate to the nature of the valuecreation practices that they engage in. The first groups we observed in Sicily were predominantly composed of multiple consumers cooperating together to engage with farmers and procure food from these farmers (Cembalo et al. 2013, 2015). Moreover, they were informal in their resource sharing, i.e. there were no written rules or contracts regulating which resources they should share, which tasks they should uptake, or which gains they should receive. Instead, their engagement in the group was based on trust relationships (Pascucci et al. 2013). Therefore, to obtain a heterogeneous set of observations, we collected data from other groups in center-northern Italy (Tuscany and Emilia-Romagna), Spain (Valencia; Miralles et al. 2017) and the Netherlands (Dentoni et al. 2015). Overall, despite more subtle differences, consumer groups were more formally organized in the centernorthern Italy and the Netherlands. For example, they often had written rules establishing the duties and benefits of members, these often included procedures to elect or nominate a leadership unit and to collect and use members' fees to be used for the purchase and distribution of food to members. In contrast, we found groups in Spain that widely ranged from formal to informal in their organization (Miralles et al. 2017). Moreover, these selected groups varied substantially in the nature of the resources shared (e.g. in some groups only food was shared, while in others even the land and agricultural inputs were shared among consumers) and in their ownership (Pascucci et al. 2013; Dentoni et al. 2015).

Analyzing and comparing these cases (for a thorough description of the empirical strategy, cfr. Pascucci et al. 2013; Dentoni et al. 2015; Miralles et al. 2017), we realized that consumers engaged in different value-creating practices across groups. On the one hand, in the groups that were sharing resources more informally, such as some groups in Valencia or our initial sample of Sicilian solidarity purchasing groups, the wide majority of consumers were engaged in processes of innovative resource redeployment (i.e. engaged in what we define as consumer entrepreneurship). On the other hand, consumers in the more formal groups showed different practices amongst each other; in particular, only a few members in leadership positions within their groups engage in consumer entrepreneurship. These 
members in leadership positions were entrepreneuring while self-creating user value through their own consumption, yet they tended to dedicate part of their time to create value for others in the organization - and exchange it with the other members in return for an allowance or salary (or, in some cases, of a discount on their group membership fee).

\section{Table 2: Illustrations on the positive relationship between informality in the sharing} group and width of participation in consumer entrepreneurship practices

\begin{tabular}{|c|c|c|}
\hline Case & $\begin{array}{l}\text { Level of formality of } \\
\text { processes regulating the } \\
\text { sharing group }\end{array}$ & $\begin{array}{l}\text { Width of group engagement in consumer } \\
\text { entrepreneurship practices }\end{array}$ \\
\hline $\begin{array}{l}\text { Private-owned } \\
\text { community } \\
\text { garden (Spain) }\end{array}$ & \multirow{4}{*}{$\begin{array}{l}\text { Informal: } \\
\text { Members pool } \\
\text { knowledge and } \\
\text { values to participate } \\
\text { to the sharing } \\
\text { organization. }\end{array}$} & $\begin{array}{l}\text { Wide: Many members participate by bringing material, } \\
\text { seeds and plants, always informally and without } \\
\text { planning. A member found a water connection for } \\
\text { irrigation close yet out of the field, and brought it in } \\
\text { without administrative troubles. }\end{array}$ \\
\hline $\begin{array}{l}\text { Consumer } \\
\text { group (Spain) }\end{array}$ & & $\begin{array}{l}\text { Wide: Members fix a day when farmers come or they go } \\
\text { to show products; farmers explain the origin of the } \\
\text { ingredients they use and then later members discuss if } \\
\text { they seem good; if so, members start testing products: } \\
\text { after every delivery (each } 15 \text { days), members make a } \\
\text { small assembly to decide on the producers. }\end{array}$ \\
\hline $\begin{array}{l}\text { Community } \\
\text { balcony (Spain) }\end{array}$ & & $\begin{array}{l}\text { Wide: Members experiment the use of light substrates } \\
\text { for the pots as they retain less water and therefore } \\
\text { decreases the added weight on the balcony. Some } \\
\text { expensive material used by members is funded through } \\
\text { various workshops and initiatives that they did to } \\
\text { support the initiative. Along with monthly fees to } \\
\text { members, financial capital is raised through courses or } \\
\text { activities done by some members, while others made T- } \\
\text { shirts sold to people who want to bring some money to } \\
\text { the project. }\end{array}$ \\
\hline $\begin{array}{l}\text { Municipality- } \\
\text { owned } \\
\text { community } \\
\text { garden (Spain) }\end{array}$ & & $\begin{array}{l}\text { Wide: Members consult each other on their previous } \\
\text { growing experience before experimenting with planting } \\
\text { new products for their own consumption. Once they } \\
\text { were given the use of the land, members adapted the } \\
\text { field. They did it in two stages, as it was a lot of ground. } \\
\text { So they decided to make a pilot experience with the first } \\
\text { half. After a year of operations, they launched together } \\
\text { the second phase. }\end{array}$ \\
\hline $\begin{array}{l}\text { Community- } \\
\text { supported } \\
\text { agriculture (The } \\
\text { Netherlands) }\end{array}$ & \multirow[t]{3}{*}{ Formal: } & $\begin{array}{l}\text { Narrow: Members helped a lot at the beginning of the } \\
\text { project but then it became less every year. This year } \\
\text { only three members actively help. These few members } \\
\text { for example organize dinners and make a white board } \\
\text { to announce something for the garden, and they invite } \\
\text { the whole group. }\end{array}$ \\
\hline $\begin{array}{l}\text { Community- } \\
\text { supported } \\
\text { agriculture (The } \\
\text { Netherlands) }\end{array}$ & & $\begin{array}{l}\text { Narrow: There is a core group of about four/five } \\
\text { members who support the farm owner with the budget } \\
\text { and also estimating financial goals and proposing } \\
\text { investments into operations. The other members refer } \\
\text { to these } 4-5 \text { members to know more about farm work } \\
\text { and finances. }\end{array}$ \\
\hline Food box & & $\begin{array}{l}\text { Narrow: Voluntary coordinators among members } \\
\text { inform the other members about the organization of }\end{array}$ \\
\hline
\end{tabular}




\begin{tabular}{|c|c|c|}
\hline $\begin{array}{l}\text { delivery scheme } \\
\text { (The } \\
\text { Netherlands) }\end{array}$ & \multirow{2}{*}{$\begin{array}{l}\text { formal. } \\
\text { Members pay for } \\
\text { food production, } \\
\text { transport and } \\
\text { delivery. }\end{array}$} & $\begin{array}{l}\text { food orders: the producers available in each season, the } \\
\text { names of the producers, the period of procurement } \\
\text { from each producer, prices, delivery frequency/time, } \\
\text { pick up points, payment systems, etc. }\end{array}$ \\
\hline $\begin{array}{l}\text { Food box } \\
\text { delivery scheme } \\
\text { (The } \\
\text { Netherlands) }\end{array}$ & & $\begin{array}{l}\text { Narrow: Few members take coordination roles in } \\
\text { between the other members and farmers as they } \\
\text { establish reputation and trust among parties. They } \\
\text { mediate the management of orders. }\end{array}$ \\
\hline
\end{tabular}

Table 2 illustrates a set of examples that offer evidence of a pattern linking the informality of relationships among sharing consumers to the width of consumer engagement in entrepreneurial practices. In other words, in the more formal consumer groups, the members in a leadership position seemed to recreate a logic of creation of exchange value with the other group members. In these same more formal groups, other members usually engaged in resource redeployment processes - yet, we observed that their processes over time lacked the innovative power that consumers in more informal groups exhibited. For example, in many community-supported agriculture groups in the Netherlands, after a first innovative phase when the members settle themselves in a peer-to-peer sharing group, we found that they tend to replicate the same actions without engaging their creativity in value-creation processes (Dentoni et al. 2015; Dentoni and Sevikul 2016). In other words, while selfcreating user value during consumption, the members without leadership roles tended to dissolve their entrepreneurial spirit as part of a more formal way of organizing.

Based on these empirical illustrations, we understood that consumers engage in entrepreneurial practices especially when their peer-to-peer sharing group organization is inherently informal. As shown in Figure 1, this pattern linking informal organization of peerto-peer sharing and consumer entrepreneurship has to do with the freedom that members have in accessing and using the resources that they may recombine. In more informal peer-to-peer groups (Figure 1a), consumers have potential access to all the resources pooled by all members - without an established rule that requires the members to focus only on recombining few resources. When the groups are more formal, instead, the members assign themselves to specific tasks (either in leadership or non-leadership positions, or in different committees focusing on specialized tasks, e.g. networking with other groups, food procurement, event organization, food inventory and storage, etc.) and, as a consequence, the set of resources that they may recombine reduces (Figure 1b). This argument leads us to advance the following proposition: the more a peer-to-peer sharing group is informally organized, the more its members engage in entrepreneurial practices that self-create user value during consumption. Ultimately, we suggest the following proposition: 


\section{Proposition 2:}

The informal organization of sharing stimulates wider member engagement in consumer entrepreneurship.

Why do more consumers engage in entrepreneurial practices when their sharing group is informally organized? One explanation emerging from our cases relates to the use of resources. In the more informal organizations, consumers have wider access to the group resources needed to create value, as well as the freedom to search and experiment in new ways and means to reach their individual and collective ends.

Figure 1: Access to resources in informal (a-b) versus formal (c-d) peer-to-peer sharing

\section{consumer groups}

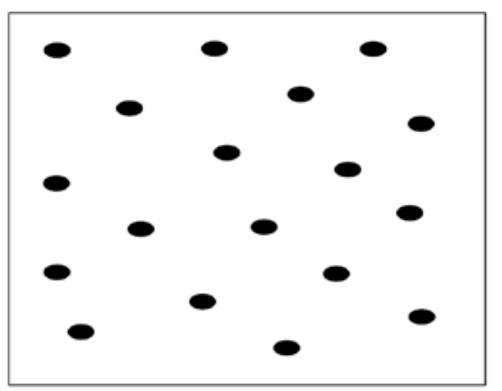

(a) The consumer group has virtually no rules and routines on which resources members should recombine to create value. Consumers have a wide choice to recombine resources innovatively.

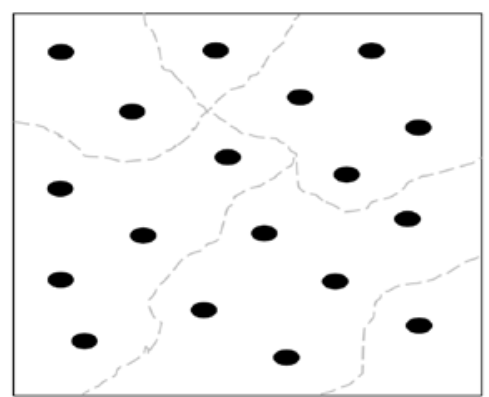

(b) The consumer group develops routines on which resources members recombine to create value. Consumers still have wide choice to recombine resources innovatively based on trust relationships

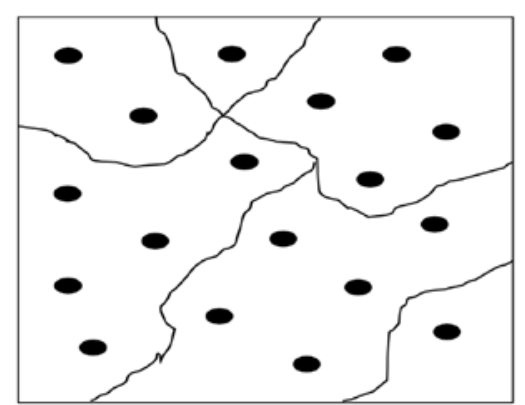

(c) The consumer group develops rules on which resources members should recombine to create value. As they uptake different tasks, consumers have a narrower choice of recombining resources innovatively based on the formal rules.

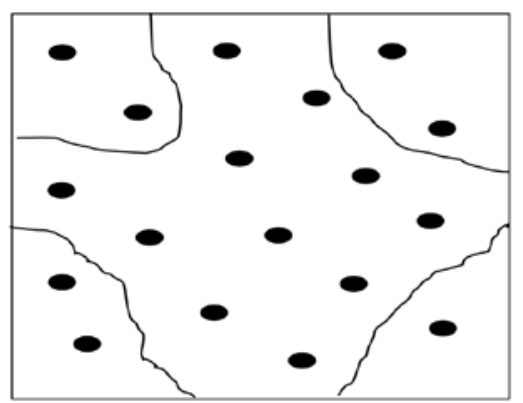

(d) The consumer group develops rules on which resources members should recombine to create value. Some consumers take leadership tasks recombining multiple resources innovatively to create exchange value, while the others recombine smaller sets of resources. 
Legend: Black dots represent resources available to consumers in the sharing group; dotted lines represent the informal routines of resource use among sharing consumers; and full lines represent the formal division of tasks among sharing consumers.

Does this argument imply that the relationship between the emergence of consumer entrepreneurship and the informality of peer-to-peer sharing is linear and stable over time? And does it imply that informal ways of sharing influence consumer entrepreneurship, rather than vice versa? Not at all. To better understand how consumer practices and their group organization co-evolves, we have further explored the food consumer group cases in Spain, Italy and the Netherlands and - to expand our evidence to another sector - we have also recently collected data from energy communities in Germany and the Netherlands. As a main difference from food peer-to-peer sharing groups, energy communities share a key hightechnology resource that stocks and transforms energy from solar or wind power. Yet, comparably with food consumer groups, consumers in energy communities also recombine knowledge, information, services and space to create value as part of their consumption. What emerged from examining these energy communities is that, in some cases (such as many solidarity purchasing groups in Italy and some community-supported agriculture groups in the Netherlands), this evolution moved groups from being highly informal to more formal (Figure 2a). For example, written rules and procedures were introduced over time. Such a formalization was mostly driven by phases of crisis in the group - due sometimes to an excessive or sudden increase of members, to lack of commitment by some members or to disagreements on some investments to make. Similar to past cases of collective organizations discussed in the literature - such as the evolution of kibbutzim in the late 1960s (Simons and Ingram 1997), the evolution of collective food, media, health and education organizations in California in the 1970s (Rothschild-Whitt 1979) or more recently the bureaucratization of software online communities in 2000s (O’Mahony and Ferraro 2007) - these groups needed to establish a more formal authority of control over time to continue creating value for the use of their members, i.e. providing fresh food or consistent energy supply. Ultimately, this process of formalization of control in our sharing organizations may have influenced the behavior of the consumers. As the theories of Etzioni (1975) and Ouchi (1979) would predict, when an organization develops more utilitarian and market-based forms of control, the involvement of its members becomes more calculative. This seems exactly what happens in some of the sharing groups that we observed over time.

Yet, less than half of our cases followed a clear trajectory of formalization over the span of our study. Instead, in other cases (in most German energy communities and across 
our cases in Spain, Italy and the Netherlands), the evolution of the peer-to-peer sharing groups did not have a direction over time and the direction appears to be cyclical (Figure 2b). In some periods, their organization seems to be moved mostly by trust relationships, while in other phases trust was going down and members felt the need of formalizing some sort of task division. In these oscillating phases over time, we realized that consumer entrepreneurship was not only an effect, but also a cause of the informality of the sharing process. Two examples in Table 3 illustrate that consumer entrepreneurship actually steered the sharing organization towards a more formal division of tasks (in the first case) and towards a more informal task division (in the second case).

Table 3: Illustrations on how consumer entrepreneurship steers the organization of sharing towards more formal/ informal division of tasks.

\begin{tabular}{|c|c|c|}
\hline Case & $\begin{array}{l}\text { Consumer entrepreneurship } \\
\text { practices }\end{array}$ & $\begin{array}{l}\text { Effects on the formal/informal } \\
\text { division of tasks }\end{array}$ \\
\hline $\begin{array}{l}\text { Consumer group } \\
\text { (Spain) }\end{array}$ & $\begin{array}{l}\text { With the increase in the number of } \\
\text { sharing consumers in the group, } \\
\text { members were struggling to } \\
\text { organize and divide the food orders } \\
\text { coming from farmers. A group of } \\
\text { members learned to develop a } \\
\text { software to automatically organize } \\
\text { the food orders from the farmers. }\end{array}$ & $\begin{array}{l}\text { From more informal to more } \\
\text { formal: As an effect to the software } \\
\text { organizing the food orders, one person } \\
\text { was assigned to the supervision of the } \\
\text { food order list throug the software. } \\
\text { After the introduction of this software, } \\
\text { the other consumers (who first had to } \\
\text { actively produce the food themselves) } \\
\text { had to only send an email alert }\end{array}$ \\
\hline $\begin{array}{l}\text { Solidarity-purchasing } \\
\text { group (Italy) }\end{array}$ & $\begin{array}{l}\text { The initial leaders of the group had } \\
\text { to move and others got carried } \\
\text { away with other commitments } \\
\text { outside the sharing group and, as a } \\
\text { result, fewer members could } \\
\text { participate actively in the group. } \\
\text { Therefore, the remaining } \\
\text { consumers in the group decided to } \\
\text { form organizing committees with a } \\
\text { clearer division of tasks. }\end{array}$ & $\begin{array}{l}\text { From more informal to more } \\
\text { formal: As an effect of the clearer } \\
\text { division of tasks, a set of rules were } \\
\text { established on the length, timing and } \\
\text { specific practices inherent with } \\
\text { uptaking different tasks in the sharing } \\
\text { organization. For example, consumers } \\
\text { mediating between farmers and other } \\
\text { group peers were required to uptake } \\
\text { their responsibility for two years and to } \\
\text { email group peers twice/week in } \\
\text { specific timeframes. }\end{array}$ \\
\hline $\begin{array}{l}\text { Private-owned } \\
\text { community garden } \\
\text { (Spain) }\end{array}$ & $\begin{array}{l}\text { Gardens where initially organized } \\
\text { as multiple private land spaces } \\
\text { allotted to different renting } \\
\text { consumers, with only few shared } \\
\text { activities linking them (water } \\
\text { irrigation, training, seed supply, } \\
\text { etc.). To create a richer experience, } \\
\text { the members organized open } \\
\text { meetings to transform their separate } \\
\text { land activity into "leisure gardens" } \\
\text { accessible especially to families } \\
\text { and children. }\end{array}$ & $\begin{array}{l}\text { From more formal to more } \\
\text { informal: The organization of open } \\
\text { meetings triggered friendship, trust and } \\
\text { reciprocity among members that } \\
\text { spontaneously decided to further } \\
\text { engage in informal activities to let their } \\
\text { children learn from the agricultural and } \\
\text { food growing experience. Moreover, } \\
\text { other sharing consumers.organized } \\
\text { social events and trainings from } \\
\text { external members in the neighborhood. }\end{array}$ \\
\hline
\end{tabular}




\begin{tabular}{|l|l|l|}
\hline $\begin{array}{l}\text { Community- } \\
\text { supported agriculture } \\
\text { (The Netherlands) }\end{array}$ & $\begin{array}{l}\text { The group was organized in a way } \\
\text { that consumers paid a monthly fee } \\
\text { to receive a box full of seasonal } \\
\text { fruit and vegetables at home, plus } \\
\text { to have access to the farm twice a } \\
\text { week to engage in shared farm } \\
\text { activities. Yet, in practice, only few } \\
\text { consumers were joining these } \\
\text { activities in person. To stimulate } \\
\text { every consumers' participation to } \\
\text { the group, the active ones decided } \\
\text { to organize a lab for making jams } \\
\text { and to deliver the food themselves } \\
\text { to the other members. }\end{array}$ & $\begin{array}{l}\text { and the food delivery from some } \\
\text { members to others triggered a number } \\
\text { of consumers' ideas for further taking } \\
\text { advantage of the farm land and } \\
\text { collective expertise. A larger number } \\
\text { of members decided to experiment } \\
\text { growing new plant varieties from their } \\
\text { home regions/countries, as well as } \\
\text { recipies for processing and eating the } \\
\text { food grown as part of the group } \\
\text { activities. }\end{array}$ \\
\hline
\end{tabular}

\section{Figure 2: Formalizing evolutions (a) versus cyclical evolutions (b) over time of peer-to- peer sharing groups}

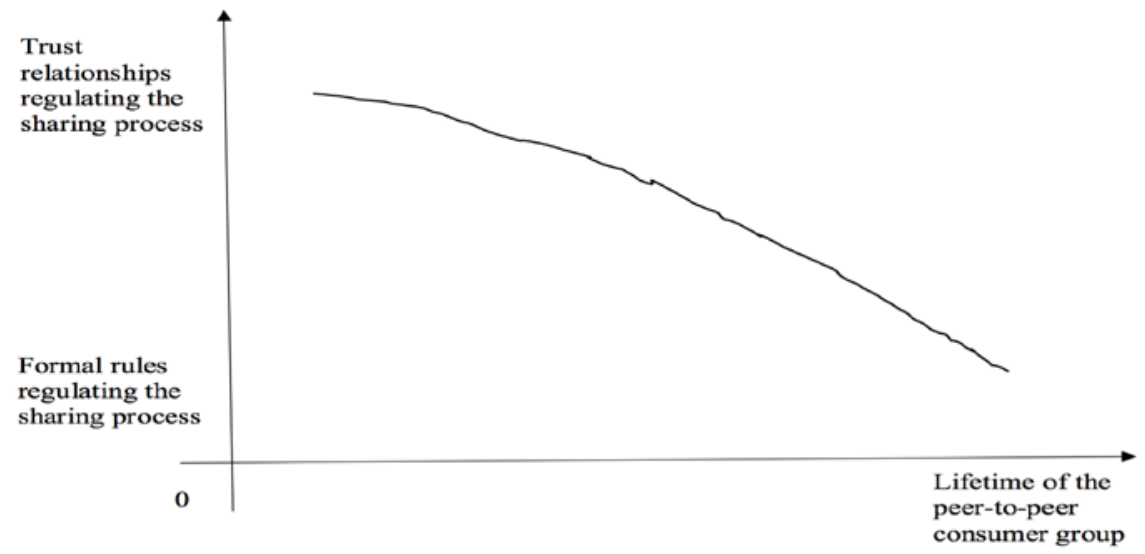

(a) Over time, the group develops formal rules that divide tasks among members. Over time, this process narrows down the resources that each consumer may recombine innovatively to self-create user value.

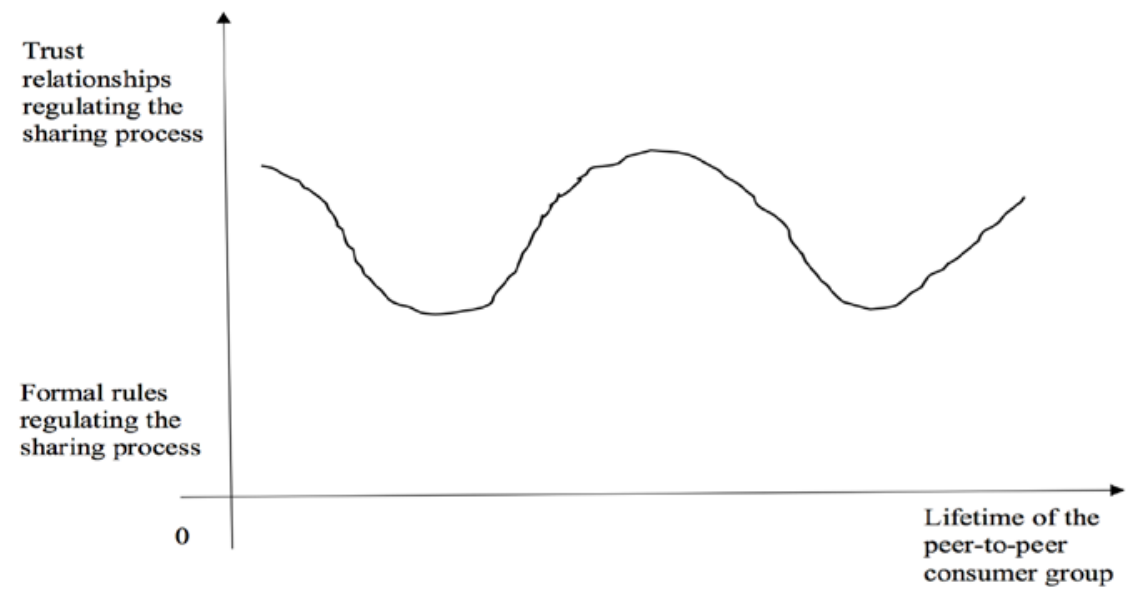

(b) Over time, trust among members fluctuates as well as their relevance in regulating the sharing process among consumers. 
Not only the organization of sharing influenced consumer entrepreneurship but also vice versa, that is, this process linking organizational control (formal/informal) and its members' behavior (more/less entrepreneurial) in sharing groups created an iterative cycle (Figure 2b). Based on these illustrations, we suggest that consumer entrepreneurship coevolves continuously with the nature of the organization, being not only in the effect but also as its driver. Therefore, to complement proposition 2, we offer proposition 3:

\section{Proposition 3:}

Consumer entrepreneurship influences change in the level of formalization of the sharing organization, either from more formal to more informal or - vice versa from more informal to more formal.

While describing the complex relationship between consumer entrepreneurship and the (in)formality of the emerging sharing organizations where it takes place, propositions 2 and 3 do not take into account why consumers inherently engage in these entrepreneurial practices. Furthermore, proposition 3 does not reveal in which direction consumer entrepreneurship steers the sharing organization towards more or less formal processes. These two knowledge gaps lead us to the core issue in section 5.

\section{Why does consumer entrepreneurship emerge?}

So far, we argued that, when they share resources with their peers, especially in informal ways, consumers engage in entrepreneurial practices. In turn, when engaging in entrepreneurial practices, consumers are likely to steer and change the organization of the sharing processes. Why? The why question is a critical question for two reasons. First, more broadly, understanding the motivations of consumers engaging in an innovative recombination of resources - no matter how small this consumer niche may currently be - has societal implications in terms of changes in everyday lifestyles and on the influences in the economic incentives of producers. Second, and more specifically, consumers' entrepreneurial practices may also influence - and not only be influenced by - the organization of their own peer-to-peer sharing groups (as discussed in section 4). Therefore, if we understand what drives consumers to engage in entrepreneurial practices in terms of (intrinsic or extrinsic) motivations, there may be clearer implications for the organization of their peer-to-peer sharing groups. 
To start tackling this why question, we first conducted a quantitative study in Italy from a sample of 303 individuals participating to three peer-to-peer sharing groups and a counterfactual of conventional grocery shoppers (Cembalo et al. 2015; Lombardi et al. 2015; Pascucci et al. 2016). We tested three potential factors associated with consumer membership to peer-to-peer sharing organizations (i.e. in this case, involving the payment of a monthly fee to receive a regular food box delivery and access to various group activities). The hypothesized drivers were consumers' universal values (Schwarz 1994), lifestyles (Brunsø et al. 2004) and consumers' transaction conditions, i.e. their perceived uncertainty on the product information, quality information, and bargaining costs (Pascucci et al. 2016). Results from this first investigation in Italy showed that consumers participating in the sampled peerto-peer sharing groups had significantly higher values of benevolence and universalism than grocery shopping consumers, indicating that an intrinsic motivation related to social, environmental and political causes was critical to their participation to the group (Lombardi et al. 2015). At the same time, even when comparing consumers with the same universal values, participants in sharing groups showed a stronger inclination to planning and carefully choosing their food products in terms of value for money, nutritional values and other process information (Cembalo et al. 2015). More specifically, participants in these sharing groups preferred to spend more time organizing new procedures of transactions to assess food product, process and price information than grocery shoppers (Pascucci et al. 2016). This first investigation helped generate an understanding - in a very specific context of three sharing organizations with a combination of formal and informal elements - that, overall, members of sharing organizations have higher values of universalism and benevolence then conventional consumers (i.e. a "social logic" to use the language of hybrids) yet, at the same time, a preference for rationally (self-) organizing and assessing more deeply the information of the food products that they consume (i.e. a more "utilitarian logic”).

To dig further into this why question, we expanded our empirical investigation to 28 sharing organizations in Spain, the Netherlands and Germany (Dentoni and Sevikul 2016; Walther 2016; Miralles et al. 2017). Moving beyond exploring reasons for participation in these organizations, as in our studies in Italy, we investigated the 1) practices that different consumers engaged in during the peer-to-peer sharing process (i.e. consumer entrepreneurship) and 2) the structure and the history of these organizations in relation to 3) the values that consumers intended to enact. In this round of investigations, we conducted semi-structured interviews and participant observations in all the 28 cases to gauge a deeper understanding on the complex relationships among these three concepts. So far, previous 
analyses were conducted only with country-level focus (Dentoni and Sevikul 2016 in Netherlands; Walther 2016 in Germany; Miralles et al. 2017 in Spain). This is the first attempt to generalize findings across countries. Overall, results across these 28 cases confirm that these two logics (social and utilitarian) co-exist in sharing organizations and their members. Looking at the data as a cross-section (i.e. in one point in time), findings overall show that sharing organizations can be described along a continuum of social and utilitarian logics. At one end of this continuum spectrum, consumer practices in some Spanish organizations had a stronger "social logic" (i.e. motivation driven by environmental, political and experiential values), associated with a wider consumer engagement in entrepreneurial practices and more informally regulated processes of sharing. For example, this is the case of community balconies inspired by an association called the Sustainable and Creative Network or of the leisure gardens organized by consumers on the land provided by a private owner. In these cases, for example, consumers decided purposively to keep the process of sharing informal to stimulate forms of collegial and personal dialogue, trust, reciprocity and empathy among members. Also from this investigation into the values driving consumer entrepreneurship, this process of wide participation led by social and political ideals and informal structures resembles early kibbutzim in the 1960s (Simons and Ingram 1997) and the early stages in the evolution of collective food, media, health and education organizations in California in the 1970s (Rothschild-Whitt 1979). Differently from these cases, though (which progressively experience a formalization within one decade of time; Simons and Ingram 1997 and Rothschild-Whitt 1979), some cases in Spain maintained wide engagement in consumer entrepreneurship and informal structures for more than twenty years. From this evidence, we state the following proposition:

\section{Proposition 4:}

\section{A social logic driving consumer entrepreneurship is associated with wider member engagement and more informal structures in sharing organizations.}

At the other end of the spectrum, instead, consumer practices in other Spanish sharing organizations and most cases in the Netherlands and Germany show a prevalence in a utilitarian logic. To clarify, consumers in these sharing groups strive for social, political and environmental ideals too. Yet, differently from the other cases, they seek to organize themselves in ways that reduce the complexity of their tasks once the sharing organization has been established. This is the case, for example, of a community sharing wind turbine 
energy in Germany: consumers have access to meetings for deciding how to develop activities that tailor energy use to all participants. Yet, after an initial stage where many showed a great deal of interest on the functioning and potential of wind power applied to their community, only few leaders continued to actively manage the community. In another case of community-supported agriculture in the Netherlands, a consumer revealed: 'compared to other community-supported agriculture (...) there is not much member participation (...). Members appreciate the activities and comment but they don't really attend or use their rights to the full extent'. Later in the same interview, the same consumer expressed: 'The reasons of being member of this farm [are] because it's organic and local. (...) Positive comments of our work are like: "vegetables taste very nice and very fresh. They can be kept for long." (...) Some negative comments are like: "There is too much lettuce, every week".' Interpreting our findings at this end of the spectrum, we suggest that some consumers in sharing organizations engage in the entrepreneurial practices to the extent that this provides them with a stronger form of assurance on the price and quality information on the shared products, such as food and energy. The behavior of consumers at this end of the spectrum seems to confirm the relationship between members' psychological ownership (i.e. feeling the organization as theirs) and their preference for formal structures that Blasi (1988) and later Pearce et al. (1991) found in the context of employee-owned organizations. Therefore, we state the fifth proposition as follows:

\section{Proposition 5:}

\section{A utilitarian logic driving consumer entrepreneurship is more associated with narrower member engagement and more formal structures in sharing organizations.}

Nevertheless, looking at the data from these 28 cases only with a cross-sectional standpoint does not yet reflect the continuously changing nature of consumers’ entrepreneurial practices and the related organization of peer-to-peer sharing. Most sharing organizations that we sampled indeed have both social and utilitarian logics co-existing with each other, similar to what described in hybrid organizations (Pache and Santos 2013; Battilana and Lee 2014). Yet, in these sharing organizations, we did not find evidence of conflict or crisis spurring from challenges in making this social and utilitarian logics co-exist. Specifically, our findings showed that consumers engaged in entrepreneurial practices in the sharing organizations as experiments to understand what themselves and others in the group 
really valued. Two examples illustrate this point. First, a consumer described her practices in a community orchard in Spain as follows: 'Since we saw that the users that were attracted by this activity were families with young children, we did and do advertising in children's magazines (...) Seeing that many children were coming to the orchard, I create a small garden in which to teach the children about gardening. Personally, I think that to have a garden gives the people a lot of joy, plus the kids really enjoy and learn a lot.' What emerged from these words is that the nature of user value emerges in a process of experimentation with other peer users - in this first case, the sharing organization revealed itself to give more value to a social logic. As a second example, a consumer revealed how he decided to develop a self-harvesting scheme with a more formal structure based on his sharing experience so far: 'People wanted to be involved in our [sharing food harvesting] process, so we are still developing this scheme. We realized that a lot of people do not know anymore where vegetable comes from. (...) That's why we chose this formula that people can harvest. (...) I think a lot of things in normal economics are going wrong because the competition between producers-consumers and producers-producers: people pay the money [for food] but this does not reflect the real price'. In other words, through a process of self-creation of user value, consumers over time develop an understanding of what they and their peers valued most and, accordingly, steered the organization of sharing processes accordingly.

This evidence seems to contradict the idea that members (specifically, founders) of emerging organizations have stable values and identities with unidirectional influence on the nature of their new venture (Fauchart and Gruber 2011; Powell and Baker 2014). Instead, our evidence shows that members (in this case, consumers) in emerging sharing organizations develop common values and identity through experimental processes of becoming. Perhaps, the difference lays in the fact that peer-to-peer sharing organizations entail multiple selforganizing members as opposed to one or a few founders as in the cases illustrated by Fauchart and Gruber (2011) and Powell and Baker (2014). As a second reason, the difference may involve the nature of the value creation process, which is self-created for personal use in sharing organizations as opposed to being created for exchange purposes in new ski equipment (Fauchart and Gruber 2011) and textile companies (Powell and Baker 2014) described in the literature. In other words, when engaging in an innovative recombination of resources for their personal use, consumers take time in the discovery and emerging phases of what constitutes value for themselves and others in their sharing organization than the founder of a new venture. Therefore, we develop this sixth and final proposition: 


\section{Proposition 6:}

\section{Consumer entrepreneurship steers the nature of self-created value in the sharing organization over time along a continuum between a social and utilitarian logic.}

These propositions lead us to a final reflection on why consumers engage in entrepreneurial practices and, through them, in organizing their sharing processes with their peers. First of all, consumer will engage in continuous processes of self-organization because they experience an adaptive tension or, as Lichtenstein et al. (2007) define this, a tension between the current and the desired state of their organization. Yet, perhaps because of the everyday nature of entrepreneurship (Steyaert and Katz 2004) in consumption, members of the sharing organizations that we analyzed seem to discover their common values along the way as opposed to enacting them from the start. In other words, a process of personal and group discovery, and thus of value emergence (Echeverri and Skålen 2011; Grönroos 2011), seems to underlie the entrepreneurial practice.

Furthermore, this process of self-organization that takes place through consumer entrepreneurial practices leads to implications on how sharing organizations integrate different social and utilitarian logics. Theory on hybrid organizations (Jay 2013; Pache and Santos 2013) and organizing (Battilana and Lee 2014) studies the processes, activities and structures that lead to an integration of competing logics, such as commercial and charity logics in social enterprises (i.e., microfinance institutions, trade unions or hospitals). Our findings, instead, reveal a different view on hybrid organizing related to consumer entrepreneurship. This view involves experimentation, discovery and evolution of these logics during a collective consumption process - that is, while in the process of use, consumers develop a common understanding on what creates value for them. This process of hybrid organizing in consumption has also broader implications for those scholars and consumers in peer-to-peer sharing organizations seeking to trigger field-level changes (i.e., tackling complex societal problems such as poverty, food insecurity, biodiversity loss or environmental degradation) (Ferraro et al. 2015). Specifically, consumer entrepreneurship seems to resonate with a pragmatist "philosophy of evolutionary learning [emphasizing] the ability of both individuals and communities to improve their knowledge and problem-solving capacity over time through continuous inquiry, reflection, deliberation and experimentation” (Ansell, 2011, p. 5). In other words, the disintegrated organization where consumers engage autonomously in value discovery, creation and use through on-going experimentation could 
be seen as a response to the complex nature of the problems that consumers seek to address through multiple logics (Ferraro et al. 2015).

\section{Conclusion}

This chapter attempted to theorize consumer entrepreneurship and discuss how it extends our knowledge of hybrid organizing (Battilana and Lee 2014) in an everyday life context (Steyaert and Katz 2004). This endeavor entailed tackling four interrelated questions, namely what consumer entrepreneurship is, as well as when, how and why it emerges. To tackle these questions, we used peer-to-peer sharing organizations as a relevant context. First of all, we define consumer entrepreneurship as the process of sharing and recombining resources innovatively to seek opportunities for self-creating user value. In other words, consumers engaging in entrepreneurial practices simultaneously self-create and use value. The ontological boundary between consumer entrepreneurship and other established definitions of entrepreneurship (Katz and Gartner 1988; Shane and Venkataraman 2000) lies mainly in the nature of the value created. While entrepreneurship traditionally involves the creation of exchange value (i.e. creating value and exchanging it for a reward), consumer entrepreneurship entails the creation of user value (Bowman and Ambrosini 2000; Priem 2007).

Second, we argue that consumer entrepreneurship emerges mostly when informal, trust-based relationships regulate the processes of peer-to-peer sharing among consumers. On the one hand, households or networks of family and friends represent a common locus for consumers to engage in informal processes of sharing, yet the available resources to recombine innovatively for consumption may be limited. On the other hand, organizations employing formal mechanisms to regulate the sharing processes (e.g. Airbnb for houses, Facebook for pictures or ZipCar for cars) establish formal boundaries to the resources that consumer can redeploy, therefore limiting the innovative potential of consumer valuecreating processes. Opposite to these two examples, grassroots forms of peer-to-peer sharing organizations - such as the cases of community gardens, community-supported agriculture, consumer groups, solidarity purchasing groups and energy communities in the Netherlands, Germany, Spain and Italy - represent organizations that, to different extents, preserved informal elements regulating the sharing process.

Third, we posit that consumer entrepreneurship evolves over time in interplay with its level of formalization. Our sampled grassroots examples of peer-to-peer sharing show that, when the organizations become more formal, fewer members engage in consumer 
entrepreneurship. This seems to reflect predictions from Etzioni (1975) and Ouchi (1979) that, when more utilitarian and market-based forms of control are instituted, members engage in more calculative and less intrinsically motivated forms of behavior. Yet, consumer entrepreneurship is not only driven by, but also drives the degree of formality of a sharing organization. In other words, the self-organization of consumption is part of the entrepreneurial process itself. As a result, consumer entrepreneurship often emerges through cyclical processes of organizing with elements spanning from more to less formal over time.

Finally, we suggest that consumer entrepreneurship stems from the need of consumers to enact a social logic, fueled mainly by their universal and benevolence values, and a utilitarian logic, which pushes them to seek more price, quality and process information on the products that they use. Along a continuum between these two logics, the organization of sharing varies from more informal (and thus with wider consumer engagement in entrepreneurial practices), when a social logic prevails, to more formal when a utilitarian logic dominates. Nevertheless, the role of these logics in the emergence of consumer entrepreneurship is not linear but involves feedback loops. That is, not only do different consumers have heterogeneous logics, but even the same consumers may fluctuate back and forth along this social-utilitarian continuum. In other words, through a process of experimenting, consumer entrepreneurship steers the nature of self-created value in the sharing organization over time along a continuum between a social and utilitarian logic.

Theorized as such, the phenomenon of consumer entrepreneurship extends the view of hybrid organizing (Battilana and Lee 2014) defined as the set of processes, practices and structures that support organizations in navigating tensions between competing institutional logics (Jay 2013; Pache and Santos 2013). Perhaps because of its inherent everyday nature (Steyaert and Katz 2004), consumer entrepreneurship entails individual and community experimentation and thus self-revelation of what constitutes value for them. As such, this process of personal and group self-discovery has been also referred to as value emergence in the marketing literature (Echeverri and Skålen 2011; Grönroos 2011). This consumer view of hybrid organizing has also implications for everyday entrepreneurs seeking to trigger fieldlevel changes to address complex societal problems (Ferraro et al. 2015). Specifically, these processes of continuous experimentation and organizational disintegration (Ansell 2011) - to the point that Western consumers self-organize to procure basic products such as food and energy - embody actions that respond to the complex nature of the problems that they seek to address. 


\section{References}

Adler, T. R., Scherer, R. F., Barton, S. L., \& Katerberg, R. (1998). An empirical test of transaction cost theory: Validating contract typology. Journal of Applied Management Studies, 7(2), 185.

Ansell, C. (2011). Pragmatist democracy: Evolutionary learning as public philosophy. Oxford University Press, New York.

Antoncic, B., \& Hisrich, R. D. (2001). Intrapreneurship: Construct refinement and crosscultural validation. Journal of business venturing, 16(5), 495-527.

Austin, J., Stevenson, H., \& Wei- Skillern, J. (2006). Social and commercial entrepreneurship: same, different, or both? Entrepreneurship theory and practice, 30(1), 1-22.

Babin, B.J., Darden, W.R., Griffin, M., 1994. Work and/or fun: measuring hedonic and utilitarian shopping. J. Cons. Research. 20 (4), 644-56.

Baker, T., \& Nelson, R. E. (2005). Creating something from nothing: Resource construction through entrepreneurial bricolage. Administrative science quarterly, 50(3), 329-366.

Bardhi, F., \& Eckhardt, G. M. (2012). Access-based consumption: The case of car sharing. Journal of Consumer Research, 39(4), 881-898.

Battilana, J., \& Lee, M. (2014). Advancing research on hybrid organizing-Insights from the study of social enterprises. The Academy of Management Annals, 8(1), 397-441.

Belk, R. (2010). Sharing. Journal of consumer research, 36(5), 715-734.

Belk, R. (2014). You are what you can access: Sharing and collaborative consumption online. Journal of Business Research, 67(8), 1595-1600.

Bowman, C., \& Ambrosini, V. (2000). Value creation versus value capture: towards a coherent definition of value in strategy. British Journal of Management, 11(1), 1-15.

Brunsø, K., Scholderer, J., \& Grunert, K. G. (2004). Closing the gap between values and behavior. A means-end theory of lifestyle. Journal of Business Research, 57(6), 665-670.

Cembalo, L., Lombardi, A., Pascucci, S., Dentoni, D., Migliore, G., Verneau, F., \& Schifani, G. (2015). "Rationally Local": Consumer Participation in Alternative Food Chains. Agribusiness, 31(3), 330-352.

Cembalo, L., Migliore, G., \& Schifani, G. (2013). Sustainability and new models of consumption: The solidarity purchasing groups in Sicily. Journal of Agricultural and Environmental Ethics, 26(1), 281-303.

Chandra, Y., \& Coviello, N. (2010). Broadening the concept of international entrepreneurship: 'Consumers as international entrepreneurs'. Journal of world business, 45(3), 228-236.

Chandra, Y., \& Leenders, M. A. (2012). User innovation and entrepreneurship in the virtual world: A study of Second Life residents. Technovation, 32(7), 464-476.

Dentoni, D., Pascucci, S., \& Migliore, G. (2015). Entrepreneurship in Consumption and the Role of Sharing. In Academy of Management Proceedings 1, 17357.

Dentoni, D. \& Sevikul, P. (2016). Linking organizational structures to entrepreneurial behaviours in sustainable business models. Journal of Cleaner Production Workshop titled "Embracing the variety of sustainable business models", May 13th, 2016, Solvay Business School (VUB), Brussels (Belgium). 
Di Domenico, M., Haugh, H., \& Tracey, P. (2010). Social bricolage: Theorizing social value creation in social enterprises. Entrepreneurship theory and practice, 34(4), 681-703.

Echeverri, P., Skålen, P., 2011. Co-creation and co-destruction: a practice theory based study of interactive value formation. Mark. Theory 11 (3), 351-373.

Fauchart, E., \& Gruber, M. (2011). Darwinians, communitarians, and missionaries: The role of founder identity in entrepreneurship. Academy of management journal, 54(5), 935-957.

Gartner, W. B. (1985). A conceptual framework for describing the phenomenon of new venture creation. Academy of management review, 10(4), 696-706.

Grönroos, C., 2011. Value co-creation in service logic: a critical analysis. Mark. Theory. 11 (3), 279-301.

Grönroos, C., Ravald, A., 2011. Service business logic: implications for value creation and marketing. J. Serv. Manag. 22(1), 5-22.

Grönroos, C., Voima, P., 2013. Critical service logic: making sense of value creation and cocreation. J. Acad. Mark. Sci. 41 (2), 133-150.

Gummesson, E., 1995. "Relationship Marketing: Its Role in the Service Economy,” in Understanding Services Management, William J. Glynn and James G. Barnes, eds. New York: John Wiley \& Sons, 244-68.

Gummesson, E., 2006. Many-to-many marketing as grand theory. In R. F. Lusch \& S. L. Vargo (Eds.), The service-dominant logic of marketing: Dialog, debate and directions (pp. 339- 353). Armonk: M.E. Sharpe.

Heinonen, K., Strandvik, T., Mickelsson, K.J., Edvardsson, B., Sund- ström, E., Andersson, P., 2010. A customer-dominant logic of service. J. Serv. Manag. 21 (4), 531-548.

Helkkula, A., Kelleher, C., Pihlström, M., 2012. Characterizing value as an experience: implications for service researchers and managers. J. Serv. Research. 15 (1), 59-75.

Hjorth, D. (2004). Creating space for play/invention-concepts of space and organizational entrepreneurship. Entrepreneurship \& Regional Development, 16(5), 413-432.

Holbrook, M. B. (1994). The nature of customer value-An axiology of services in the consumption experience. In R. T. Rust \& R. L. Oliver (Eds.), Service quality: New directions in theory and practice. Thousand Oak: Sage.

Holbrook, M. B. (1999). Introduction to consumer value. In M. B. Holbrook (Ed.), Customer value. A framework for analysis and research (pp. 1-28). London: Routledge.

Johannisson, B. (2011). Towards a practice theory of entrepreneuring. Small Business Economics. 36, 135-150.

Katz, J., \& Gartner, W. B. (1988). Properties of emerging organizations. Academy of management review, 13(3), 429-441.

Lamberton, C. P., \& Rose, R. L. (2012). When is ours better than mine? A framework for understanding and altering participation in commercial sharing systems. Journal of Marketing, 76(4), 109-125.

Lee, E.J., Overby, J.W., 2004. Creating value for online shoppers: implications for Satisfaction and Loyalty. J. Cons. Satisf., Dissatisf. and Compl. Beh. 17: 54-67.

Lombardi, A., Migliore, G., Verneau, F., Schifani, G., \& Cembalo, L. (2015). Are "good guys” more likely to participate in local agriculture?. Food Quality and Preference, 45, 158- 
165.

Mair, J., \& Marti, I. (2006). Social entrepreneurship research: A source of explanation, prediction, and delight. Journal of world business, 41(1), 36-44.

Marti, I., Courpasson, D., \& Barbosa, S. D. (2013). “Living in the fishbowl”. Generating an entrepreneurial culture in a local community in Argentina. Journal of Business Venturing, 28(1), 10-29.

Miralles, I., Dentoni, D. \& Pascucci, S. (2017). Understanding the organization of sharing economy in agri-food systems: Evidence from Alternative Food Networks in Valencia. Agriculture and Human Values, In Press.

Nicolini, D. (2012). Practice theory, work, and organization: An introduction. Oxford university press.

O'Mahony, S., \& Ferraro, F. (2007). The emergence of governance in an open source community. Academy of Management Journal, 50(5), 1079-1106.

Pache, A. C., \& Santos, F. (2013). Inside the hybrid organization: Selective coupling as a response to competing institutional logics. Academy of Management Journal, 56(4), 9721001.

Pascucci, S., Dentoni, D., Lombardi, A., \& Cembalo, L. (2011). Food Community Networks. European Association of Agricultural Economists (EAAE) 2011 Congress on "Change and Uncertainty Challenges for Agriculture, Food and Natural Resources”, August 30rdSeptember 2nd, 2011, ETH Zurich, Zurich, Switzerland.

Pascucci, S., Lombardi, A., Cembalo, L., \& Dentoni, D. (2013). Governance mechanisms in food community networks. Italian Journal of Food Science, 25(1), 98.

Peredo, A. M., \& Chrisman, J. J. (2006). Toward a theory of community-based enterprise. Academy of Management Review, 31(2), 309-328.

Peredo, A. M., \& McLean, M. (2006). Social entrepreneurship: A critical review of the concept. Journal of world business, 41(1), 56-65.

Powell, E. E., \& Baker, T. (2014). It's what you make of it: founder identity and enacting strategic responses to adversity. Academy of Management Journal, 57(5), 1406-1433.

Priem, R. L. (2007). A consumer perspective on value creation. Academy of Management Review, 32(1), 219-235.

Rothschild-Whitt, J. (1979). The collectivist organization: An alternative to rationalbureaucratic models. American Sociological Review, 509-527.

Sage, C. (2003). Social embeddedness and relations of regard:: alternative 'good food' networks in south-west Ireland. Journal of rural studies, 19(1), 47-60.

Sánchez-Fernández, R., Iniesta-Bonillo, M.Á., 2007. The concept of perceived value: a systematic review of the research. Mark. Theory. 7 (4), 427-451.

Scaraboto, Daiane. "Selling, sharing, and everything in between: The hybrid economies of collaborative networks." Journal of Consumer Research 42.1 (2015): 152-176.

Schatzki, T. R., 1996. Social practices: a Wittgensteinian approach to human activity and the social. Cambridge, Cambridge University Press.

Schwartz, S. H. (1994). Are there universal aspects in the structure and contents of human values? Journal of Social Issues, 50, 19-45. 
Seabright, P. (2000). The vanishing rouble: Barter networks and non-monetary transactions in post-Soviet societies. Cambridge University Press.

Seelos, C., \& Mair, J. (2005). Social entrepreneurship: Creating new business models to serve the poor. Business horizons, 48(3), 241-246.

Shah, S. K., \& Tripsas, M. (2007). The accidental entrepreneur: The emergent and collective process of user entrepreneurship. Strategic Entrepreneurship Journal, 1(1-2), 123-140.

Shane, S., \& Venkataraman, S. (2000). The promise of entrepreneurship as a field of research. Academy of management review, 25(1), 217-226.

Sheth, J.N., Newman, B.I., Gross, B.L., 1991. Consumption values and market choices: theory and applications. Cincinnati, OH: South-Western Publishing Co.

Sheth, J.N.,\& Uslay, C. (2007). Implications of the Revised Definition of Marketing: From Exchange to Value Creation. American Marketing Association, 26 (2), 302-307.

Simons, T., \& Ingram, P. (1997). Organization and ideology: Kibbutzim and hired labor, 1951-1965. Administrative Science Quarterly, 784-813.

Stark, D. (2011) What's valuable? In: The Worth of Goods: Valuation and Pricing in the Economy, edited by Patrik Aspers and Jens Beckert (Oxford University Press, 2011).

Steyaert, C., \& Katz, J. (2004). Reclaiming the space of entrepreneurship in society: geographical, discursive and social dimensions. Entrepreneurship \& regional development, 16(3), 179-196.

Steyaert, C. (2007). 'Entrepreneuring' as a conceptual attractor? A review of process theories in 20 years of entrepreneurship studies. Entrepreneurship and regional development, 19(6), 453-477.

Thompson, C. J., Locander, W. B., Pollio, H. R., 1989. Putting consumer experience back into consumer research: the philosophy and method of existential-phenomenology. J. Cons. Research. 16 (2), 133-47.

Turner, S. (2001). Throwing out the tacit rule book: learning and practices. The practice turn in contemporary theory. Psychology Press. London.

Vargo, S.L. Lusch, R.F., 2004. Evolving to a new dominant logic for marketing. J. Mark. 68 (1), 1-17.

Walther (2016). The relationship between trust and leadership/followership behavior in community energy projects: How the organizational structure and participants' behavior interrelate in an example of the sharing economy? MSc thesis, Management Studies Group, Wageningen University and Research.

Webb, J.W., Bruton, G. D., Tihanyi, L. and Ireland, R. D. (2013). Research on entrepreneurship in the informal economy: Framing a research agenda. Journal of Business Venturing, 28(5), 598-614. 